\title{
PENGARUH PEMBERIAN YOGHURT KACANG MERAH TERHADAP KADAR TRIGLISERIDA PADA WANITA DISLIPIDEMIA
}

\author{
Angela Astrid Pramesti, Martha Irene Kartasurya*) \\ Program Studi Ilmu Gizi Fakultas Kedokteran Universitas Diponegoro \\ J1.Dr.Sutomo No.18, Semarang, Telp (024) 8453708, Email : gizifk@ undip.ac.id
}

\begin{abstract}
Background : The prevalence of Cardiovascular Disease (CVD) increased during last years. High resistant starch in red bean may decrease triglyceride levels. Processed red bean will result in higher antioxidant which increase isoflavon activity to improve triglyceride levels.

Aim: To analyze the effect of red bean yoghurt on triglycerides levels on dyslipidemic women.

Methods : This research was a true experimental study. Subjects were 37 women with serum triglycerides $\geq 100 \mathrm{mg} / \mathrm{dL}$ who divided into two groups, control group (consumed low caloris syrup) and treatment group (consumed $225 \mathrm{ml}$ red bean yoghurt per day). Red bean yoghurt was consumed for 15 days. Triglycerides level was measured with CHODPAP method. Food intake during intervention was measured using 24-hours food recall. Physical activity was measured by IPAQ. Shapiro-Wilk was used to analyze data normality. The statistical analysis used were dependent ttest, Wilcoxon, independent t-test and Mann Whitney tests.

Result : Median of triglycerides level before and after intervention in the treatment group were $136 \pm 47.7 \mathrm{mg} / \mathrm{dL}$ and $114 \pm 45.9 \mathrm{mg} / \mathrm{dL}$, and in control group were $172 \pm 14.8 \mathrm{mg} / \mathrm{dL}$ and $169 \pm 28.0 \mathrm{mg} / \mathrm{dL}$. Reduction of triglycerides level on treatment group was higher $(p=0.006)$ than the control group which was $22 \mathrm{mg} / \mathrm{dL}(13,1 \%)$ compared to the control group $3 \mathrm{mg} / \mathrm{dL}(1.7 \%)$.

Conclusion : Red bean yogurt consumption of $225 \mathrm{ml}$ for 15 days decrease triglycerides level in dyslipidemic premenopausal women.
\end{abstract}

Keyword : Red bean yoghurt, triglycerides, dyslipidemia, pre-menopausal women.

\begin{abstract}
ABSTRAK
Latar Belakang : Penyakit Kardiovaskuler (PKV) merupakan salah satu penyakit degeneratif yang cenderung meningkat dari tahun ke tahun. Resistant starch (RS) yang tinggi pada kacang merah dapat menurunkan kadar trigliserida. Kacang merah yang diolah menjadi yoghurt memiliki aktivitas antioksidan berupa isoflavon yang lebih tinggi dibanding tanpa pengolahan sehingga mampu memperbaiki kadar trigliserida darah.

Tujuan: Menganalisis pengaruh pemberian yoghurt kacang merah terhadap kadar trigliserida darah pada wanita dislipidemia

Metode : Jenis penelitian adalah true experimental. Subjek penelitian adalah 37 wanita dengan kadar trigliserida $\geq 100 \mathrm{mg} / \mathrm{dL}$ yang kemudian dibagi menjadi dua kelompok secara acak. Kelompok perlakuan diberi yoghurt kacang merah sebanyak $225 \mathrm{ml} / \mathrm{hari}$ dan kelompok kontrol diberi sirup rendah kalori. Intervensi dilakukan selama 15 hari. Kadar trigliserida diukur menggunakan metode CHOD-PAP. Asupan makanan sebelum dan selama intervensi diukur menggunakan metode food recall $3 \times 24$ jam dan dianalisis menggunakan program nutrisurvey. Aktivitas fisik dianalisis menggunakan IPAQ. Uji normalitas menggunakan Shapiro Wilk. Analisis statistik menggunakan uji Wilcoxon, independent t-test dan Mann Whitney.

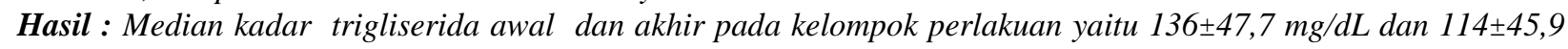

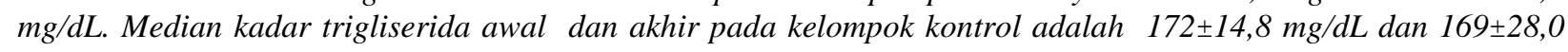
mg/dL. Penurunan kadar trigliserida pada kelompok perlakuan lebih banyak ( $(13,1 \%)$, sedangkan kelompok kontrol sebesar $3 \mathrm{mg} / \mathrm{dL}(1,7 \%)$. Kadar Trigliserida 35\% subjek kelompok perlakuan menjadi normal setelah intervensi.
\end{abstract}

Kesimpulan : Pemberian yoghurt kacang merah 225 ml/hari selama 15 hari menurunkan kadar Trigliserida wanita pre-menopause dengan dislipidemia.

Kata kunci : Yoghurt kacang merah, trigliserida, dislipidemia, wanita pre menopause

\section{PENDAHULUAN}

Penyakit Kardiovaskuler (PKV) merupakan salah satu penyakit degeneratif yang cenderung meningkat dari tahun ke tahun. Laporan World Health Organization (WHO) 2008 menyebutkan 17,5 juta manusia meninggal akibat penyakit kardiovaskular. Jumlah ini setara dengan 30\% total kematian di dunia pada tahun 2008. Tahun 2030 diprediksi penyakit kardiovaskuler dapat menyebabkan kematian sekitar 23,3 juta manusia di dunia. $^{1}$

Berdasarkan beberapa penelitian dan jurnal ilmiah, prevalensi penyakit kardiovaskular yang meningkat diperkirakan berhubungan dengan pola

\footnotetext{
${ }^{*}$ Penulis Penanggungjawab
} 
makan dan asupan tinggi lemak hewani tetapi rendah sayur dan buah. Konsumsi tinggi lemak, rendah serat dan antioksidan merupakan salah satu faktor risiko penyakit jantung. ${ }^{2}$ Faktor risiko penyakit kardiovaskular lainnya telah diketahui diantaranya adalah merokok, gaya hidup sedentary, obesitas, aktivitas fisik, peningkatan tekanan darah, diabetes, dan ketidaknormalan fraksi lemak (dislipidemia). ${ }^{3}$ Suatu penelitian menyebutkan bahwa dislipidemia merupakan faktor risiko terpenting dalam proses terjadinya aterosklerosis dan berhubungan kuat dengan terjadinya penyakit kardiovaskular. ${ }^{4}$ Dislipidemia merupakan kelainan metabolisme lemak yang ditandai dengan peningkatan atau penurunan profil lemak dalam plasma. Kelainan profil lemak yang paling utama adalah kenaikan kadar trigliserida, kolesterol LDL, kenaikan kadar kolestrol total serta penurunan kadar HDL. $^{5}$

Salah satu alternatif untuk menurunkan profil lemak adalah melalui terapi non-farmakologis (perubahan gaya hidup) yang meliputi terapi gizi medis (modifikasi diet), aktivitas fisik, serta beberapa upaya lain seperti menghindari rokok, menurunkan berat badan dan pembatasan asupan alkohol. ${ }^{6}$ Modifikasi diet yang diterapkan adalah dengan mengurangi asupan lemak total dan lemak jenuh serta meningkatkan asupan lemak tidak jenuh tunggal dan ganda. ${ }^{78}$ Konsumsi bahan makanan dengan efek hipokolestrolemia juga dianjurkan salah satunya adalah kacang merah. ${ }^{8,9,10}$ Kombinasi dari serat dan makanan dengan efek hipokolesterolemia mampu menurunkan kadar trigliserida sebesar $13,53 \% .{ }^{11}$ Contoh makanan yang mengandung efek hipokolestrolemia salah satunya adalah kacang merah. Kacang merah diketahui mengandung zat gizi seperti polifenol, kaya akan asam folat, kalsium, karbohidrat kompleks, serat, dan protein yang tergolong tinggi. ${ }^{9}$ Resistant starch (RS) yang tinggi pada kacang merah menjadikan kacang merah dapat menurunkan kadar trigliserida dan trigliserida serum karena memiliki sifat serat terlarut maupun tidak terlarut. ${ }^{8,10}$

Kacang merah yang telah diolah akan memiliki aktivitas antioksidan yang lebih tinggi. Proses pengolahan kacang merah akan menghidrolisis isoflavon menjadi senyawa isoflavon bebas yang disebut aglikon. Aglikon memiliki aktivitas lebih tinggi dalam memperbaiki trigliserida serum. ${ }^{12}$ Suatu penelitian menyatakan bahwa pengolahan kacang merah dengan cara fermentasi akan menghasilkan senyawa isoflavon bebas yang terbanyak. ${ }^{13}$ Salah satu produk hasil fermentasi dari kacang merah adalah yoghurt kacang merah. Yoghurt kacang merah merupakan hasil dari fermentasi susu kacang merah oleh bakteri asam laktat (BAL). Penelitian yang dilakukan pada tikus dislipidemia yang diberi jus kacang merah, yoghurt susu, dan yoghurt kacang merah $(4 \mathrm{ml})$ selama 28 hari menunjukkan bahwa penurunan kadar trigliserida $(\mathrm{p}<0,05)$ terjadi pada kelompok yang diberikan yoghurt kacang merah yaitu sebesar $0,3 \pm 0,02 \mathrm{mg} / \mathrm{dl} .{ }^{8}$

\section{METODE}

Subjek penelitian ini adalah karyawati kantor Badan Perencanaan Pembangunan Daerah Provinsi Jawa Tengah (BAPPEDA), karyawati SMP Domenico Savio Yayasan Pangudi Luhur, Semarang dan karyawati di SD Bernardus Yayasan Pangudi Luhur, Semarang. Kriteria inklusi yang ditetapkan untuk subjek penelitian adalah karyawati yang berusia $\geq 30$ tahun, memiliki kadar trigliserida $\geq 100 \mathrm{mg} / \mathrm{dl},{ }^{14}$ belum menopause, tidak sedang mengonsumsi obat antidislipidemia selama penelitian, tidak dalam keadaan sakit atau dalam perawatan dokter berkaitan dengan penyakit jantung koroner, diabetes melitus, hipertensi, gagal ginjal, dan penyakit kronik lainnya. Perhitungan banyaknya jumlah subjek penelitian yang diperlukan mengikuti rumus uji hipotesis terhadap rerata dua populasi independen dan didapatkan hasil sebanyak 16 subjek minimal tiap kelompok. Mengantisipasi adanya drop-out (DO), maka jumlah subjek tiap kelompok ditambah 25\% dari total subjek minimal, sehingga jumlah subjek keseluruhan tiap kelompok adalah sebanyak 20 subjek.

Penelitian ini bersifat true eksperimental yaitu dengan memberikan intervensi pada kelompok perlakuan dan kontrol. ${ }^{15}$ Kelompok perlakuan diberikan yoghurt kacang merah sebanyak $225 \mathrm{ml} / \mathrm{hari}$ dan kelompok kontrol diberikan sirup rendah kalori. Pada proses skrining awal peneliti memperoleh 51 orang karyawati yang bersedia diambil darahnya. Dari 51 orang tersebut, terdapat 40 orang yang memenuhi kriteria inklusi dan dipakai sebagai subjek penelitian yang kemudian dibagi menjadi 2 kelompok masingmasing 20 orang. Sebanyak tiga orang dalam kelompok kontrol dinyatakan drop out (DO) karena dua orang berhalangan hadir pada saat pengambilan darah berlangsung dan satu orang sedang dalam perawatan dokter, sehingga jumlah subjek akhir penelitian adalah sebanyak 37 orang yaitu 20 orang pada kelompok perlakuan dan 17 orang pada kelompok kontrol. Rincian subjek adalah 15 orang karyawati di SMP Domenico Savio dan 22 orang karyawati di BAPPEDA Semarang. 
Eksperimen dilakukan selama 15 hari. Kelompok kontrol dan kelompok perlakuan diberikan konseling mengenai diet rendah kolesterol dan lemak terbatas. Asupan makan sehari-hari untuk kedua kelompok tidak dikontrol. Metode dan analisis yang digunakan selama intervensi adalah metode food recall 24 jam yang diberikan selama intervensi, yang kemudian dianalisis dengan program nutrisurvey. Penggunaan kuesioner aktivitas fisik International Physical Activity Questionnaire (IPAQ) untuk meninjau aktivitas fisik responden. Selama penelitian, subjek diharuskan untuk melaporkan aktivitas fisik terkait kegiatan yang dilakukan selama tujuh hari terakhir. Perhitungan skor aktivitas fisik berdasarkan protokol skoring IPAQ dan dinyatakan dalam satuan MET-menit/minggu. Penggolongan skor berdasarkan klasifikasi rendah $(<600$ METmenit/minggu), sedang (600-2999 METmenit/minggu), dan tinggi $(\geq 3000$ METmenit/minggu). ${ }^{13}$ Klasifikasi Indeks Massa Tubuh ditentukan dengan kategori normal (18,5 - 22,9 $\mathrm{kg} / \mathrm{m}^{2}$ ), overweight $\left(23-24,9 \mathrm{~kg} / \mathrm{m}^{2}\right)$ dan obesitas (> $\left.25 \mathrm{~kg} / \mathrm{m}^{2}\right){ }^{17} \quad$ Pemeriksaan kadar trigliserida dilakukan sebelum dan setelah intervensi (hari ke16). Pengukuran kadar trigliserida dilakukan dengan metode Cholesterol Oxidase Para Aminophenazone (CHOD-PAP). Subjek diharuskan berpuasa selama \pm 10 jam sebelum subjek darah diambil petugas laboratorium.

Uji kenormalan data menggunakan uji Shapiro-Wilk, dan diperoleh bahwa data tidak berdistribusi normal. Untuk melihat gambaran karakteristik subjek digunakan analisis deskriptif. Uji beda kadar trigliserida sebelum dan sesudah intervensi digunakan uji Wilcoxon dikarenakan data tidak berdistribusi normal. Uji beda pengaruh konsumsi yoghurt kacang merah terhadap trigliserida digunakan uji Mann-Whitney dkarenakan data tidak berdistribusi normal. ${ }^{16}$

\section{HASIL PENELITIAN \\ Karakteristik Subjek}

Subjek dalam penelitian berjumlah 37 orang, 20 orang pada kelompok perlakuan dan 17 orang pada kelompok kontrol. Keadaan subjek pada awal penelitian dapat dilihat pada Tabel 1 .

Tabel 1. Karakteristik subjek

\begin{tabular}{|c|c|c|c|}
\hline \multirow{2}{*}{ Variabel } & Perlakuan $(\mathrm{n}=20)$ & Kontrol (n=17) & \multirow[b]{2}{*}{$\mathbf{p}$} \\
\hline & Mean \pm SD & Mean \pm SD & \\
\hline Umur (tahun) & $42,9 \pm 6,3$ & $42,2 \pm 7,2$ & $0,927^{\mathrm{a}}$ \\
\hline Indeks Massa Tubuh $\left(\mathrm{kg} / \mathrm{m}^{2}\right)$ & $27 \pm 4,57$ & $26,6 \pm 4,93$ & $0,816^{\mathrm{a}}$ \\
\hline Aktivitas fisik (MET-menit/minggu) & $937,9 \pm 796,6$ & $1196,5 \pm 2289,4$ & $0,287^{\mathrm{a}}$ \\
\hline
\end{tabular}

${ }^{a}$ Mann-Whitney test

Tabel 1 menunjukkan bahwa semua variabel pada kedua kelompok tersebut homogen dikarenakan tidak terdapat perbedaan nilai variansi antara kategori umur, Indeks Massa Tubuh (IMT), dan aktivitas fisik (AF) pada awal penelitian pada kelompok perlakuan dan kelompok kontrol sebelum dilakukan intervensi. Karakteristik subjek untuk IMT dan aktivitas fisik dapat dilihat dalam Tabel 2.

Tabel 2. Kiteria IMT dan Aktivitas Fisik subjek

\begin{tabular}{lcccc}
\hline \multicolumn{1}{c}{ Variabel } & \multicolumn{2}{c}{ Perlakuan $(\mathbf{n = 2 0})$} & $\mathbf{n}$ & Kontrol (n=17) \\
\cline { 2 - 5 } & $\mathbf{n}$ & $\mathbf{\%}$ & & \\
\hline Indeks Masa Tubuh & & & 5 & $29,4 \%$ \\
$\quad$ Normal & 5 & $25 \%$ & 3 & $17,6 \%$ \\
Overweight & 1 & $5 \%$ & 9 & $52,9 \%$ \\
Obesitas & 14 & $70 \%$ & 12 & $70,6 \%$ \\
\hline Aktivitas fisik & & & 4 & $23,5 \%$ \\
$\quad$ Rendah & 10 & $50 \%$ & 1 & $5,9 \%$ \\
Sedang & 10 & $50 \%$ & $0 \%$ & \\
Tinggi & 0 & $0 \%$ &
\end{tabular}

Tabel 2 menunjukkan bahwa sebagian besar subjek pada kelompok perlakuan berada pada kategori obesitas yaitu sebanyak 14 orang (70\%), dan pada kelompok kontrol juga sebagian besar subjek berada pada kategori obesitas yaitu sebanyak 9 orang $(52,9 \%)$. Kategori aktivitas fisik menunjukan bahwa sebanyak 10 orang subjek $(50 \%)$ dari kelompok perlakuan tergolong dalam aktivitas rendah dan 10 orang lainnya (50\%) tergolong aktifitas sedang, sedangkan pada kelompok kontrol sebagian besar subjek temasuk 
dalam kategori aktifitas rendah yaitu sebanyak 12 orang $(70,6 \%)$.

\section{Asupan Zat Gizi Selama Intervensi}

Berdasarkan perhitungan recall pada subjek penelitian selama intervensi, dapat diketahui kondisi kecukupan kebutuhan zat gizi pada kedua kelompok. Asupan zat gizi selama intervensi pada kelompok perlakuan dan kontrol terdapat pada Tabel 3.

Tabel 3. Persen Kecukupan Kebutuhan Zat Gizi dan Asupan Kolesterol Selama Intervensi

\begin{tabular}{lccc}
\hline & Perlakuan $(\mathbf{n}=\mathbf{2 0})$ & Kontrol $(\mathbf{n}=\mathbf{1 7})$ & p \\
\cline { 2 - 3 } & Median \pm SD & Median \pm SD & \\
\hline Tingkat kecukupan energi (\%) & $98,2 \pm 28,6$ & $101,8 \pm 22,4$ & $0,141^{\mathrm{a}}$ \\
Tingkat Kecukupan karbohidrat * $(\%)$ & $67,5 \pm 15,47$ & $69,7 \pm 15,95$ & $0,542^{\mathrm{a}}$ \\
Tingkat kecukupan lemak* $(\%)$ & $60,3 \pm 38,7$ & $90 \pm 34$ & $0,187^{\mathrm{a}}$ \\
Tingkat Kecukupan protein* $(\%)$ & $90,4 \pm 9,81$ & $87,2 \pm 14,1$ & $0,419^{\mathrm{b}}$ \\
Tingkat kecukupan serat* $(\%)$ & $27,2 \pm 17,2$ & $33,1 \pm 13,1$ & $0,063^{\mathrm{a}}$ \\
Asupan kolesterol $(\mathbf{m g})$ & $196,6 \pm 64,7$ & $210 \pm 109,3$ & $0,784^{\mathrm{a}}$ \\
\hline
\end{tabular}

*dihitung berdasarkan AKG 2013

a Mann Whitney

${ }^{\mathrm{b}} \mathrm{Uji}$ beda independent $t$-test

Tabel 3 menunjukkan bahwa tidak terdapat perbedaan antara tingkat kecukupan energi, karbohidrat, lemak, protein, serat, dan asupan kolesterol, pada kedua kelompok. Persentase kecukupan energi subjek dihitung berdasarkan perbandingan antara asupan subjek dengan asupan idealnya yang menggunakan rumus Harris Benedict, dan persentase asupan gizi lainnya merupakan perbandingan antara asupan subjek dengan asupan idealnya yang dihitung berdasarkan pedoman AKG 2013.

\section{Tingkat Asupan Yoghurt Kacang Merah}

Kelompok perlakuan mendapatkan intervensi berupa yoghurt kacang merah sebanyak
$225 \mathrm{ml} /$ hari selama penelitian. Peneliti melakukan peninjauan dan pencatatan dari sisa yoghurt kacang merah yang dikonsumsi subjek. Sisa yoghurt kacang merah menunjukkan tingkat asupan yoghurt kacang merah yang dikonsumsi oleh subjek. Tingkat asupan yogurt kacang merah selama eksperimen dilakukan adalah sebesar $100 \%$.

Perbedaan Kadar Trigliserida Sebelum dan Setelah Intervensi.

Uji beda pada kadar trigliserida sebelum dan setelah intervensi menggunakan uji MannWhitney. Hasil dari uji beda tersebut dapat dilihat pada tabel 4.

Tabel 4. Perbedaan Kadar Trigliserida sebelum dan setelah intervensi

\begin{tabular}{|c|c|c|c|}
\hline \multirow[t]{2}{*}{ Variabel } & Perlakuan $(n=20)$ & Kontrol $(n=17)$ & \multirow[t]{2}{*}{$\mathbf{p}$} \\
\hline & Median \pm SD & Median \pm SD & \\
\hline \multicolumn{4}{|l|}{ Kadar TG (mg/dL) } \\
\hline Sebelum & $136 \pm 47,7$ & $172 \pm 14,8$ & 0,063 \\
\hline Setelah & $114 \pm 45,9$ & $169 \pm 28,0$ & $0,002^{\mathrm{a}}$ \\
\hline Perubahan (setelah-sebelum) & $-22 \pm 30,4$ & $-3 \pm 23,8$ & $0,006^{\mathrm{a}}$ \\
\hline \% Perubahan & $-13,1$ & $-1,7$ & \\
\hline $\mathbf{p}$ & $0,001^{\mathrm{b}}$ & $0,831^{\mathrm{b}}$ & \\
\hline
\end{tabular}

Hasil uji beda menunjukan terdapat perbedaan antara kadar trigliserida pada kelompok perlakuan dan kelompok kontrol. Terdapat perbedaan antara penurunan kadar trigliserida pada kedua kelompok. Terdapat perbedaan antara sebelum dan setelah intervensi pada kelompok perlakuan. Dilihat dari data statistik, tidak terdapat perbedaan antara kadar trigliserida pada saat sebelum dan setelah intervensi pada kelompok kontrol, namun secara deskriptif pada kelompok perlakuan terjadi penurunan kadar trigliserida sebanyak $13,1 \%$ sedangkan pada kelompok kontrol terjadi penurunan sebanyak $1,7 \%$.

Sebelum dilakukan intervensi, kadar trigliserida pada kedua kelompok tergolong tinggi $(\geq 100 \mathrm{mg} / \mathrm{dL})$. Setelah intervensi selama 15 hari, pada kelompok perlakuan sebanyak 16 orang mengalami penurunan terdiri dari 7 subjek (35\%) 
pada kelompok perlakuan menjadi normal, 9 (45\%) subjek mengalami penurunan namun dengan kadar trigliserida yang masih dalam kategori tinggi, dan 4 (20\%) subjek tidak mengalami penurunan. Sebanyak 9 (59\%) subjek pada kelompok kontrol mengalami penurunan, akan tetapi, semuanya masih dengan kadar trigliserida yang masih dalam kategori tinggi dan 8 (47\%) subjek tidak mengalami penurunan.

\section{PEMBAHASAN}

Aktivitas fisik mampu menurunkan kadar trigliserida, namun pengaruh penurunanya cenderung berbeda pada setiap individu. Hal ini dipengaruhi oleh intensitas, durasi aktivitas, dan kadar trigliserida awal. Penurunan yang paling efektif terjadi jika aktivitas fisik yang dilakukan pada tingkat sedang sampai tinggi, disertai dengan kadar trigliserida $>150 \mathrm{mg} / \mathrm{dl} .{ }^{21}$ Sebagian subjek termasuk dalam kategori aktivitas fisik rendah (<600 MET-menit/minggu), yaitu sebesar 50\% (10 subjek) pada kelompok perlakuan dan 70,6\% (12 subjek) pada kelompok kontrol. Berdasarkan pengkajian aktivitas fisik subjek, diketahui bahwa subjek berada di kantor dan hanya bekerja di depan meja kerja selama hari kerja sehingga jarang berolahraga. Berdasarkan uji Mann-Whitney, tidak ada perbedaan antara aktivitas fisik pada kelompok kontrol dan perlakuan, oleh karena itu, aktifitas fisik bukan merupakan faktor perancu pada penelitian ini.

Asupan karbohidrat berperan dalam meningkatnya kadar trigliserida, efek peningkatan ini terjadi jika jumlah asupan karbohidrat melebihi kebutuhan. Glukosa akan diubah menjadi glukosa 6 fosfat, selanjutnya glukosa 6 fosfat mengalami perubahan menjadi gliserol 3 fosfat, dimana gliserol 3 fosfat mengalami reaksi esterifikasi dengan asam lemak menjadi trigliserida. Asupan zat gizi lain seperti protein juga dapat mempengaruhi kadar trigliserida darah. Asam amino yang terdapat pada protein diubah menjadi asetil KoA yang berperan dalam biosintesis trigliserida didalam tubuh sehingga, apabila asupan protein berlebihan, asam amino yang berasal dari protein akan disimpan dalam bentuk trigliserida. ${ }^{22}$ Asupan lemak dapat meningkatkan kadar trigliserida, $\pm 90 \%$ lemak pada makanan dalam bentuk trigliserida, trigliserida akan diangkut oleh kilomikron dan langsung di edarkan ke seluruh tubuh, dengan demikian peningkatan asupan lemak akan meningkatkan kadar trigliserida. ${ }^{23}$ Hasil penelitian menunjukan bahwa nilai median pada persen kecukupan energi, karbohidrat, protein, dan lemak dibawah 100\%, hal ini dikarenakan saat proses recall, waktu untuk wawancara terbatas dan jawaban yang diberikan oleh subjek tidak lengkap. Berdasarkan uji MannWhitney, menunjukkan bahwa tidak ada perbedaan antara persen kecukupan asupan energi, karbohidrat, protein, dan lemak pada kelompok perlakuan maupun kelompok kontrol, sehingga dapat disimpulkan bahwa tingkat kecukupan asupan bukan merupakan faktor perancu dalam penelitian ini.

Kelompok perlakuan mendapatkan intervensi berupa asupan yoghurt kacang merah selama 15 hari. Pemberian yoghurt kacang merah menurunkan kadar trigliserida. Hal ini dibuktikan dengan terjadinya penurunan kadar trigliserida pada kelompok perlakuan. Tidak terdapat perbedaan antara kadar trigliserida saat sebelum dan setelah intervensi pada kelompok kontrol, hal ini menunjukkan bahwa pada kelompok kontrol tidak mengalami penurunan kadar trigliserida.

Penurunan kadar trigliserida pada kelompok perlakuan ini lebih baik dibandingkan penelitian sebelumnya yaitu pemberian yoghurt kacang merah $4 \mathrm{ml} / \mathrm{hari}$ selama 28 hari terhadap tikus dislipidemia yang menurunkan kadar trigliserida namun tidak signifikan. ${ }^{8}$ Penurunan trigliserida pada kelompok perlakuan disebabkan karena kandungan RS dan isofalvon dalam kacang merah dan bakteri asam laktat dalam yoghurt. Kacang merah mengandung Resistant starch (RS) tipe $1, \mathrm{RS}$ adalah jenis pati yang resisten atau tidak dapat dicerna dalam saluran cerna manusia oleh karena itu RS termasuk dalam golongan prebiotik. ${ }^{18}$ Resistant starch mampu menurunkan kadar trigliserida, hal ini disebabkan karena RS mampu mengikat kolesterol, asam empedu dan asam lemak dalam usus halus. Pengikatan kolesterol, asam empedu, dan asam lemak oleh RS akan mengurangi pembentukan miselle sehingga lemak tersebut keluar bersama feces. ${ }^{18,24}$ Resistant starch mengalami fermentasi oleh bakteri probiotik sehingga menghasilkan asam lemak rantai pendek seperti asam propionat. Asam propionat mampu menurunkan kadar trigliserida dengan menghambat lipogenesis di hati, hal ini dapat menyebabkan penurunan sintesis asam lemak. Asam lemak adalah bahan baku untuk membuat trigliserida. ${ }^{18,25}$

Bakteri asam laktat (BAL) pada yoghurt kacang merah berperan untuk mengikat trigliserida di dalam lumen usus. ${ }^{26}$ Bakteri asam laktat juga mempunyai peran dalam mengoksidasi isoflavon pada kacang merah yoghurt sehingga menghasilkan senyawa isoflavon bebas yang disebut aglikon. Aglikon memiliki aktivitas yang lebih tinggi untuk menurunkan kadar trigliserida. ${ }^{8}$ Isoflavon mengaktifkan Peroxisome Proliferatoractivated 
Receptor $\alpha$ (PPAR $\alpha$ ), dimana PPAR $\alpha$ mengakibatkan penurunan aktifitas gen yang memproduksi ketersediaan trigliserida untuk Very Low Density Lipoprotein (VLDL) dan meningkatkan aktivitas lipoprotein lipase. Lipoprotein lipase mempunyai peran sebagai lipolisis trigliserida pada kilomikron dan VLDL. ${ }^{27}$

Faktor lain yang mempengaruhi penurunan trigliserida adalah pemberian konseling gizi. Kedua kelompok mendapatkan konseling gizi mengenai diet rendah kolesterol dan lemak terbatas. Tujuan diberikannya konseling gizi agar ada perubahan kebiasaan dan pola makan pada subjek..$^{20}$ Konseling diberikan satu kali saat pertengahan intervensi pada kedua kelompok, akan tetapi, pemberian konseling tersebut tidak mencapai target dikarenakan proses konseling hanya dilakukan satu kali saja, selain itu subjek yang diberikan konseling kurang memperhatikan konseling yang diberikan, baik pada kelompok kontrol maupun perlakuan. Kegagalan konseling gizi ini dibuktikan dengan tidak adanya perbedaan kadar trigliserida sebelum dan setelah intervensi pada kelompok kontrol.

\section{SIMPULAN}

Hasil penelitian membuktikan bahwa pemberian yoghurt kacang merah dengan dosis 225 $\mathrm{ml} /$ hari selama 15 hari menurunkan kadar trigliserida pada wanita dengan dislipidemia ringan.

\section{DAFTAR PUSTAKA}

1. World Health Organization. 2011. Global Atlas on cardiovascular disease prevention and control. Hal 8. Available from URL: http://www.world-heartfederation.org/fileadmin/user upload/documents/P ublications/Global_CVD_Atlas.pdf

2. Sulastri D, Rahayuningsih S, Purwantyastuti. Pola Asupan Lemak, Serat, dan Antioksidan, serta Hubungannya dengan Profil Lipid pada Laki-laki Etnik Minangkabau. Artikel Penelitian Mahasiswa FK Universitas Andalas Padang; 2005.

3. Badan Penelitian dan Pengembangan Kesehatan Kementrian Kesehatan RI. 2013. Riset Kesehatan Dasar.

4. Bittner V. Perspectives on Dyslipidemia and Coronary Heart Disease in Women. Journal of American College of Cardiology 2005; 46(9):1632.

5. Anwar, Bahri T. Dislipidemia Sebagai Faktor Resiko Penyakit Jantung Koroner. 2004. Medan: Universitas Sumatera Utara.

6. Perkumpulan Endokrinologi Indonesia (Perkeni). Petunjuk Praktis Penatalaksanaan Dislipidemia. 2004.

7. Varady KA, Peter JHJ. Combination Diet and Exercise Interventions for the Treatment of Dyslipidemia: an Efective Preliminary Strategy to
Lower Cholesterol Levels. Journal of Nutrition 2005; 135 (8):1829-30.

8. Rachmandiar R. Perbedaan Pengaruh Jus Kacang Merah, Yoghurt Susu, dan Yoghurt Kacang Merah Terhadap Kadar Kolesterol Total dan Trigliserida Serum pada Tikus Dislipidemia. Artikel Karya Tulis Ilmiah Mahasiswa Program Studi Kedokteran Umum. FK. Undip Semarang; 2012.

9. Sai-Ut S, Ketnawa S, Chaiwut P, Rawdkuen S. Biochemical and functional properties of proteins from red kidney, navy and adzuki beans. As J Food Ag-Ind. 2009; 2(04), 493-504.

10. Bowerman S. High-carbohydrate foods, with their Resistant starches, are back. EarthSave News [Serial onine] 2008 [cited 2014 july 16] Available from URL

http://www.earthsave.org/news/resistantstarches.ht $\underline{\mathrm{m}}$

11. Jenkins DJA, Kendall CWC, Faulkner FA, Nguyen T, Kemp T, Marchie A, et al. Assessment of the longer-term effects of a dietary portfolio of cholesterol-lowering foods in hypercholesterolemia. Am J Clin Nutr.

12. Wu Z, Song L, Huang D. Polyphenolic antioxidants and phytoalexins changes in germinating legume seeds with food grade fungal Rhizopusoligoporus Stress. J Agric Food Chem. 2011.

13. International Physical Activity Questionnaire (IPAQ). Guidelines for data processing and analysis of the international physical activity questionnaire (IPAQ). Short and long Form. Revised November 2005. Available from www.ipaq.ki.se.

14. Floyd P, Mimms S, Elding C. Personal Health: Prespective and Lifestyles. The Basics of Nutrition. 2008. p.274.

15. Notoatmodjo S. Metodologi Penelitian Kesehatan. Jakarta: Rineka Cipta; 2012.p.58, 182;3.

16. Dahlan SM. Statistik untuk Kedokteran dan Kesehatan. Jakarta: Salemba Medik. 2012. p.16, 45.

17. WHO expert consultation. Appropriate Body-Mass Index for Asian Populations and its Implications for Policy and Intervention Strategies. Lancet. 2004; 363: $157-63$

18. Zaragoza F.E, Navarrete RMJ, Zapata ES, Alvarez PJA . Resistant starch as functional ingredient: A review. Elsevier. 2010; 931-42

19. Holli BB, Judith AB. Nutrition Counseling and Education Skill for Dietetics Professionals. 6th ed. Philadelphia: Wolter Kluwer, Lippincott Williams and Wilkins; 2013.p.1.

20. Andreson JW, Dee AD, Susan RB.Soluble Fiber Hypocholesterolemic Effects and Proposed Mechanisms. In: Kritchevsky D, Charles B, James WA, editors. Dietary Fiber Chemistry, Physiology, and Health Effects. New York: Plenum Press; 1990.p.350-6.

21. Miller M, Stone NJ, Ballantyne C, Bittner V, Criqui MH, Ginsberg HN, et al. Triglycerides and Cardiovascular Disease: A Scientific Statement From the American Heart Association. Circulation. 
2011;123:2292-2333. Available from : http://circ.ahajournals.org/content/123/20/2292

22. Botham KM, Peter AM. Bioenergetika \& Metabolisme Karbohidrat dan Lipid. Dalam: Murray RK, Darly KG, Victor WR, editor. Braham UP, alih bahasa. Biokimia Harper. 27 ed. Jakarta: EGC; 2009.p. 140

23. Hidayati SN, Hadi H, Lestariana W. Hubungan Zat Gizi dan Indeks Masa Tubuh dengan Hiperlipidemia pada Murid SLTP yang obesitas di Yogyakarta. Sari Pediatri vol.8, No. 1; 2006.p 2531.

24. Rakhmiditya HA, Kartini A. Pengaruh Pemberian Snack Bar Berbahan Dasar Kombinasi Ubi Jalar Ungu dan Kedelai (Hitam dan Kuning) Terhadap Kadar Trigliserida pada Wanita Dewasa Hipertrigliseridemia. Journal of Nutrition Collage, Vol. 3, No. 1; 2014; 106-16.

25. Nair KK, Kharb S, Thompkinson DK. Inulin Dietary Fiber with Functional and Health Attributes-A Review. 2010. Food Reviews International; 26:189-203.

26. Baiduri I. Pengaruh Pemberian Yoghurt Kedelai Hitam Terhadap Kadar Trigliserida Serum pada Tikus Hipertrigliseridemia. Artikel Karya Tulis Ilmiah Mahasiswa Program Studi Ilmu Gizi. FK. Undip Semarang; 2011.

27. Medjakovic S, Mueller M, Jungbauer A. Potential Health-modulating Effects of Isoflavones and Metabolites via Activation of PPAR and AhR. Nutrients; 2010.p. 241-279. 